\title{
Stepwise capillary electrophoretic separation of DNA fragments using poly(ethylene oxide) solutions in the presence of electroosmotic flow
}

\author{
Hsuan-Shen Chen, Huan-Tsung Chang* \\ Department of Chemistry, National Taiwan University, P.O. Box 23-34, Roosevelt Road Sect. 4, No. 1, Taipei 10764, Taiwan
}

\begin{abstract}
Single-base resolution in the separation of DNA markers V and VI was achieved in the presence of electroosmotic flow (EOF), using poly(ethylene oxide) (PEO) solutions containing ethidium bromide (EtB) under isocratic conditions. Furthermore, a new approach called stepwise capillary electrophoresis (SCE) has been developed for DNA analysis, including stepwise changes in PEO concentration, EtB concentration as well as both PEO and EtB concentrations, wherein the EOF was used to introduce different PEO solutions into the capillary during the separation. DNA fragments smaller than $80 \mathrm{bp}$ were both detected under isocratic conditions using $20 \mu \mathrm{g} / \mathrm{ml} \mathrm{EtB}$, and SCE using 1 and $20 \mu \mathrm{g} / \mathrm{ml} \mathrm{EtB}$, but not under isocratic conditions using $1 \mu \mathrm{g} / \mathrm{ml} \mathrm{EtB}$. Resolution and speed of the DNA separation in SCE were different from those obtained from isocratic means, indicating that DNA underwent different concentrations of PEO and EtB in SCE. For example, DNA fragments with 458 and 504 base pairs (bp) were partially resolved in SCE, but not under isocratic conditions. The results further suggest that it is worth developing gradient techniques for widening the separation range and enhancing resolution in DNA analysis. (C) 1999 Elsevier Science B.V. All rights reserved.
\end{abstract}

Keywords: Buffer composition; Stepwise capillary electrophoresis; DNA; Poly(ethylene oxide); Ethidium bromide

\section{Introduction}

Capillary electrophoresis (CE) is a powerful method for DNA analysis because of its high resolving power and extremely high speed [1-3]. Recently, replaceable polymer solutions prepared from linear polymers, such as linear polyacrylamide (LPA) [4], cellulose [5], and poly(ethylene oxide) (PEO) [6], have been commonly used for high-resolution DNA analysis. It is noted that single-base resolution of DNA up to several hundred bases has been demonstrated using LPA solutions [7].

Intercalating dyes, such as ethidium bromide

*Corresponding author.

E-mail address: changht@mail.ch.ntu.edu.tw (H.-T. Chang)
(EtB), are commonly used for the DNA analysis in $\mathrm{CE}$ with laser-induced fluorescence (LIF) detection system [8]. It has been reported that the DNA chain becomes longer and stiffer, and the net charges of the DNA fragments decrease after forming complexes with cationic intercalating dyes [9-11]. As a consequence, intercalated DNA migrates more slowly than pure DNA, and the band becomes narrower [12]. It has also been shown that the mobility and fluorescence intensity of the intercalated DNA depend on DNA/dye ratios, indicating that a better separation result might be achieved by carefully choosing the species and concentration of cationic intercalating dyes. Furthermore, gradient techniques with a capability of introducing different concentrations and/or species of the intercalating dyes 
should be useful for enhancing efficiency in the separation of DNA.

Techniques providing single-base resolution and high speed are important for detecting point mutations of DNA, PCR products, and DNA sequencing $[13,14]$. Up to date, the method with single-base resolution is only good for the separation of small DNA fragments because of the lack of a suitable polymer solution for separating a wide size range of DNA. It has been suggested that the relative size between pores of polymer solution and DNA is an important factor in determining resolution [15]. Thus performing gradient techniques to induce the change in DNA conformations and/or to introduce different pore-size polymer solutions into the capillary seems to be optimistic for extending the separation range in the analysis of DNA. Gradient techniques, such as temperature [16] and voltage [17], have been demonstrated in $\mathrm{CE}$ for detecting point mutations in the analysis of small alterations in DNA sequence of genomic materials. Slight changes in the mobilities of DNA molecules, resulting from the changes in DNA conformations, account for the high-resolution result. Unfortunately, these methods are only suitable for separating certain sizes of DNA fragments. On the other hand, capillary pore gradient gel electrophoresis (CPGGE) is more useful for widening the separation range, increasing resolution, and shortening total separation time in the separation of DNA $[18,19]$. However, such gradient techniques are difficult to perform in CE since capillaries are not easily filled with different pore-size polymer solutions. Recently, polydispersed polymer solutions prepared from different sizes of PEO have been used for the separation of DNA fragments ranging from 18 to $2176 \mathrm{bp}$ in $30 \mathrm{~min}$ [20]. More recently, a sophisticated method has been used to prepare PA gradient gel matrices for the separation of oligosaccharides and poly(Asp) in CE [21], indicating that this method might be useful for enhancing resolution in the analysis of DNA. However poor reproducibility, bubble formation, and short lifetime of the capillary are common problems when PA is polymerized inside the capillary. In consequence, this technique is not suitable for the high-throughput analysis of DNA using multiplexed systems because obtaining reproducible results from different capillaries is very important [22-24].
In the presence of electroosmotic flow (EOF), filling capillaries with polymer solutions of varying pore sizes seems to be feasible. Recently, we took advantage of a relatively high EOF to introduce PEO solutions into capillaries for high-resolution DNA separations without the need of filling polymer solutions prior to separations $[25,26]$. One of the advantages of performing this new method is that we can regenerate fresh capillary surface each time, and thus a highly viscous polymer solution can be reproducibly introduced into a very small-size capillary. This may be useful for high-resolution DNA separations, which is important in DNA sequencing and DNA diagnosis. In addition, it is possible to perform CPGGE for the analysis of DNA of varying sizes using the EOF to introduce different polymer solutions into the capillary during the separation.

In this work, a new method with a capability of introducing different polymer solutions during DNA analysis was demonstrated. Herein, the hypothesis that better results in the DNA separation can be achieved in the presence of EOF in SCE using different PEO solutions was tested. Another objective of this work is to examine the effects of the changes in EtB and PEO concentrations on speed and resolution in the separation of DNA markers $\mathrm{V}$ and VI.

\section{Materials and methods}

\subsection{Equipment}

The basic design of the separation system has been previously described [20]. Briefly, a high-voltage power supply (Gamma High Voltage Research, Ormond Beach, USA) was used to drive electrophoresis. The entire detection system was enclosed in a black box with a HV interlock. High-voltage end of the separation system was put in a home-made plexiglass box for safety. A $1.5-\mathrm{mW} \mathrm{He}-\mathrm{Ne}$ laser with $543.6 \mathrm{~nm}$ output from Melles Griot (Irvine, CA, USA) was used for excitation. The light was collected with a $10 \times$ objective $($ N.A. $=0.25)$. One RG 610 cutoff filter was used to block scattered light before the emitted light reaches the phototube (Hamamatsu R928). The fluorescence signal was transferred directly through a $10-\mathrm{k} \Omega$ resistor to a 
24-bit A/D interface at $10 \mathrm{~Hz}$ (Borwin, JMBS Developments, Le Fontanil, France) and stored in a personal computer. Capillaries (Polymicro Technologies, Phoenix, AZ, USA) with $75 \mu \mathrm{m}$ I.D. and $365 \mu \mathrm{m}$ O.D. were used for DNA separations without any further coating process.

\subsection{Chemicals}

All chemicals for preparing buffer solutions were from Aldrich (Milwaukee, WI, USA). EtB was obtained from Molecular Probes (Eugene, OR, USA). The buffer solutions were $1 \times$ TBE ( $89 \mathrm{~m} M$ Tris, $89 \mathrm{~m} M$ boric acid and $2 \mathrm{~m} M$ EDTA) containing different amounts of EtB in the absence and presence of different amounts of PEO $\left(M_{\mathrm{r}} 8 \cdot 10^{6}\right)$. DNA markers $\mathrm{V}$ and VI were purchased from Boehringer Mannheim (Mannheim, Germany).

\subsection{Preparation of PEO solutions}

Certain amounts of PEO were gradually added into the $1 \times \mathrm{TBE}$ buffer solutions in a beaker stirring in a water bath at $85-90^{\circ} \mathrm{C}$. During the addition of PEO, a magnetic stirring rod was used at high speed to produce a well homogenized solution. After the addition was complete, the solution was stirred for at least one more hour. Finally, polymer solutions were degassed with a vacuum system in an ultrasonic tank. Polymer solutions stored in a refrigerator at $4^{\circ} \mathrm{C}$ were usable for at least a week.

\subsection{Separation}

Prior to analysis, capillaries were treated with 0.5 $M \mathrm{NaOH}$ overnight. After each run, capillaries were washed with $0.5 M \mathrm{NaOH}$ at $0.5 \mathrm{kV}$ for $10 \mathrm{~min}$ to remove polymer solutions and refresh the capillary wall. Twenty-five $\mu \mathrm{g} / \mathrm{ml}$ DNA was injected into the capillary filled with TBE buffer containing EtB at 1 $\mathrm{kV}$ for $5 \mathrm{~s}$. Then the injection end of the capillary was moved into PEO solutions. During the separation, PEO solutions were migrated into the capillary via the high EOF for sieving DNA fragments. In the stepwise experiment, $1 \times$ TBE containing EtB were filled prior to injection of DNA, 1\% PEO containing EtB were introduced into the capillaries via the EOF for a certain time after injection of
DNA, then 2\% PEO containing EtB via the EOF for the rest of the separation. More details see Section 3.

\subsection{Calculation}

Resolution $\left(R_{s}\right)$ was calculated using Eq. (1).

$R_{\mathrm{s}}=2\left(t_{2}-t_{1}\right) /\left(t_{\mathrm{w} 1}+t_{\mathrm{w} 2}\right)$

where $t_{1}$ and $t_{2}$ are the migration times, and $t_{\mathrm{w} 1}$ and $t_{\mathrm{w} 2}$ are the width of the peak at baseline for fragments 1 and 2, respectively.

\section{Results and discussion}

\subsection{Isocratic separation}

Fig. 1 shows the separation of DNA markers $\mathrm{V}$ and VI, ranging from 8 to 2176 base pairs (bp) in the presence of EOF, using a $1 \%$ PEO solution containing $1 \mu \mathrm{g} / \mathrm{ml}$ EtB. DNA fragments larger than 80 bp were separated in less than $12 \mathrm{~min}$. It should be noted that larger DNA fragments were detected earlier than small ones since larger DNA fragments were retarded more effectively by PEO matrices when they migrated upstream against the EOF. The results show not only single-base resolution between 123- and 124-bp DNA fragments, but also partial resolution between two 154-bp DNA fragments. Unlike the result shown in Fig. 1, Fig. 2 shows that DNA fragments larger than $51 \mathrm{bp}$ were detected in less than $20 \mathrm{~min}$ at $15 \mathrm{kV}$, using $2 \%$ PEO solution containing $1 \mu \mathrm{g} / \mathrm{ml} \mathrm{EtB}$. Although resolution between 123- and 124-bp DNA fragments is worse, resolution values between two 154-bp, and between 540- and 587-bp DNA fragments become larger. From the baseline shift in Figs. 1, 2 (not clearly shown in the whole scale of the electropherograms), we knew that the EOF is smaller in a $2 \%$ PEO solution. The result suggests that the longer migration time using the $2 \%$ PEO solution might result from the higher viscosity and more adsorption of the PEO molecules in the capillary surface.

It is difficult to detect smaller DNA fragments in the presence of EOF because the fluorescence intensities are weak and the electrophoretic mobilities (EPMs) of the smaller intercalated DNA fragments 


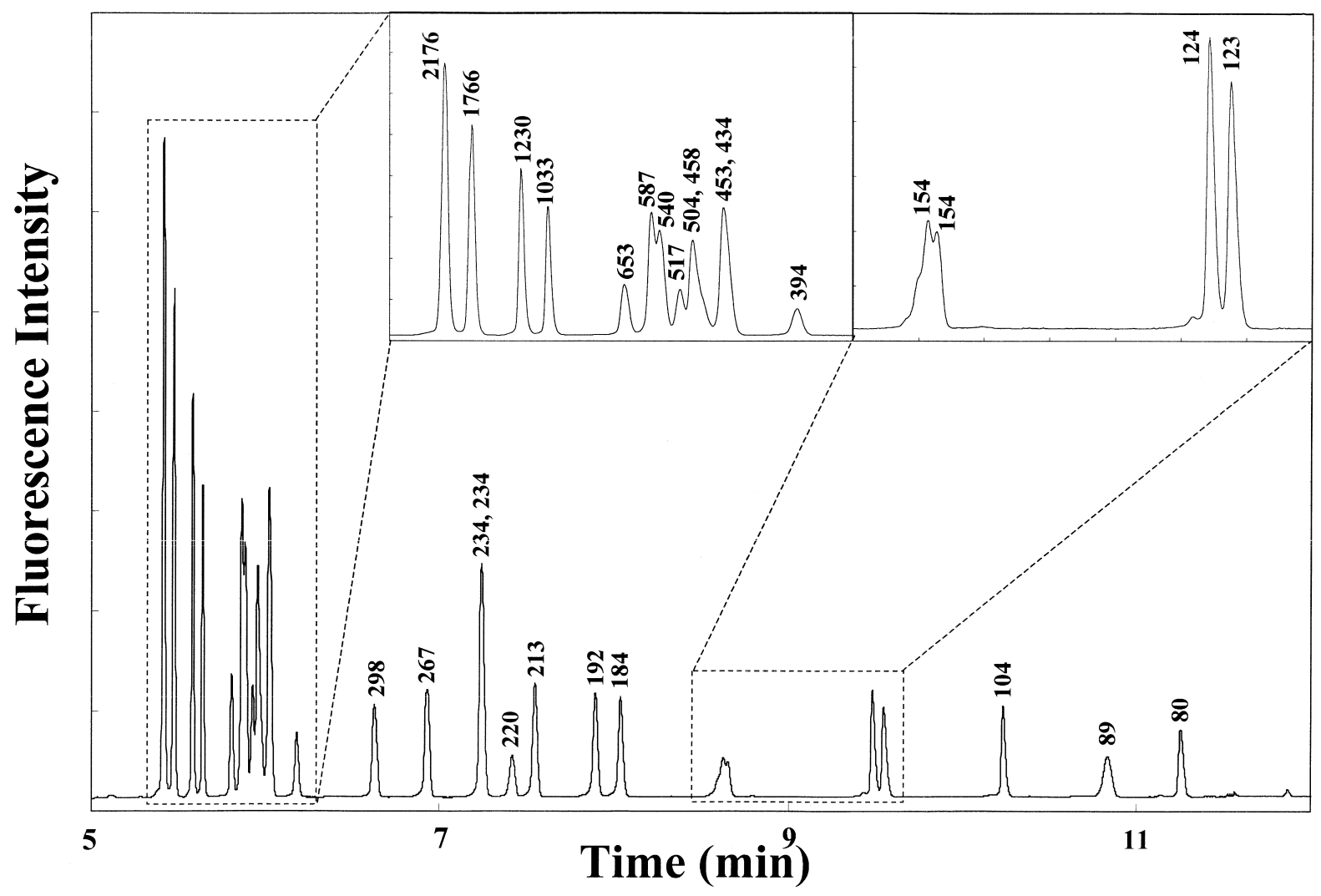

Fig. 1. Separation of DNA markers V and VI in the presence of EOF at $15 \mathrm{kV}$, using a $1 \%$ PEO $\left(M_{\mathrm{r}} 8000000\right)$ solution containing $1 \mu \mathrm{g} / \mathrm{ml}$ EtB. Capillary: $40 \mathrm{~cm}$ in total length and $30 \mathrm{~cm}$ in effective length; filled with $1 \times$ TBE containing $1 \mu \mathrm{g} / \mathrm{ml} \mathrm{EtB}$. Buffer vials contain the $1 \%$ PEO and $1 \mu \mathrm{g} / \mathrm{ml} \mathrm{EtB}$ solution.

are high. In order to detect smaller DNA fragments, several approaches might be worth trying, such as increasing the EOF, decreasing the DNA mobility, and/or enhancing the sensitivity of the detection system. For example, a higher EOF can be achieved using a more suitable polymer solution with lower ionic strengths. On the other hand, decreases in the mobility of DNA can be approached using suitable intercalating dyes and smaller pore-size polymer solutions. It is also important to choose suitable dyes (e.g. bisintercalating dyes such as TOTO) with optimal concentrations for enhancing the sensitivity.

To further shorten separation times and enhance the detection capability for smaller DNA fragments, we performed the separation using a 2\% PEO solution containing $20 \mu \mathrm{g} / \mathrm{ml}$ EtB. Fig. 3 shows the separation of DNA makers V and VI at $15 \mathrm{kV}$ in less than $12 \mathrm{~min}$. The shorter separation times indicate that the EPMs of DNA fragments decreased after forming intercalated complexes with EtB because the EOF almost remained constant in PEO solutions containing different amounts of EtB. The reduction should be due to the decrease in the net charges and elongation of the DNA fragments. Moreover, the higher resolution values between 123- and 124-bp, and two 234-bp DNA fragments were observed in the presence of high concentrations of EtB.

\subsection{Why SCCE?}

Although the separation of DNA in the presence of EOF has been shown for many years, this method has only been applied to the separation of large DNA fragments using ultradiluted polymer solutions $[27,28]$. The restriction to the use of high concentrations of polymer solution is mainly due to the 


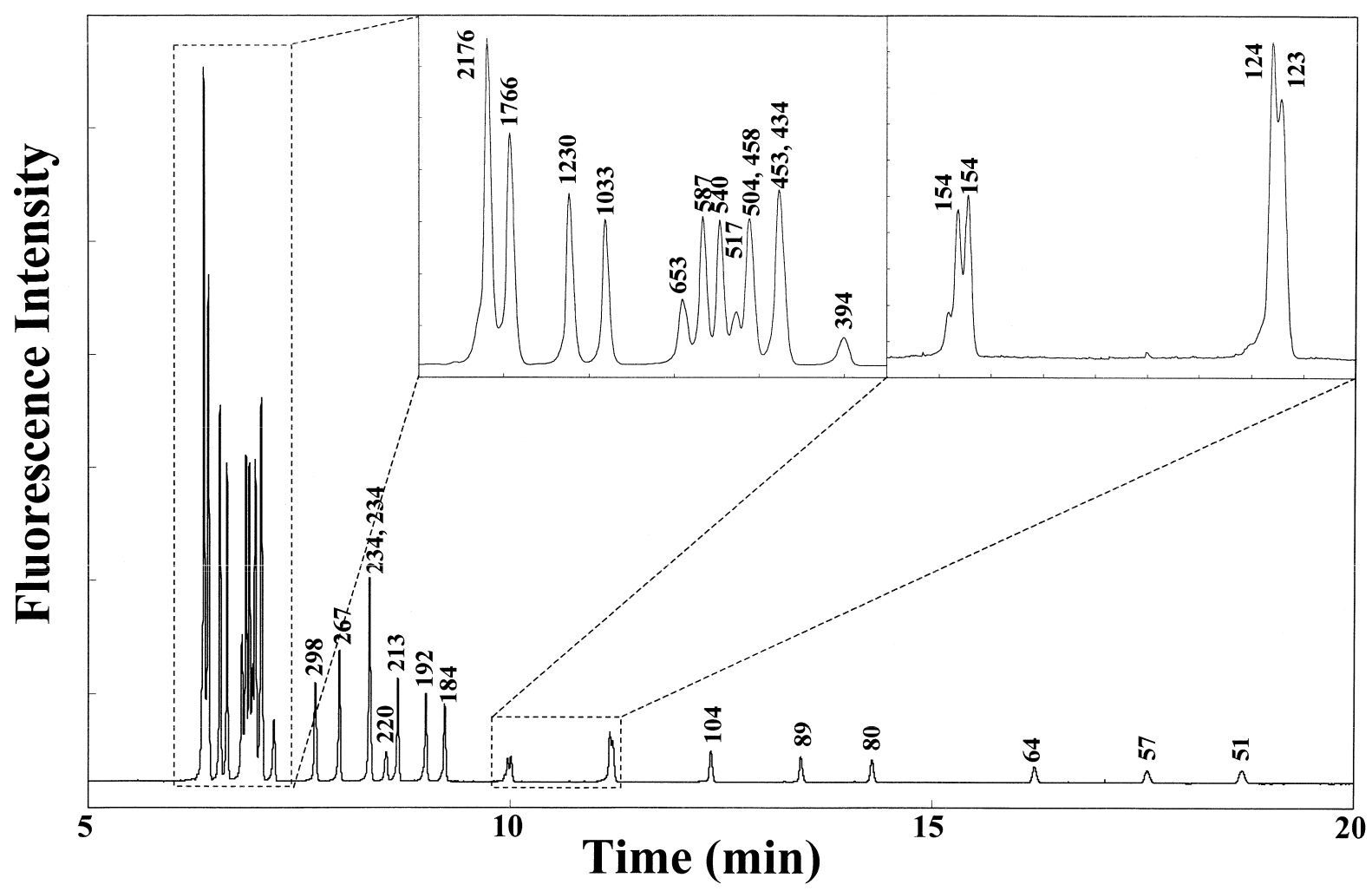

Fig. 2. Separation of DNA markers V and VI in the presence of EOF at $15 \mathrm{kV}$, using a $2 \%$ PEO solution containing $1 \mu \mathrm{g} / \mathrm{ml}$ EtB. Buffer vials contain the $2 \% \mathrm{PEO}$ and $1 \mu \mathrm{g} / \mathrm{ml}$ EtB solution. Other conditions as in Fig. 1.

decrease in the EOF, wherein the adsorption of the polymer molecules into the capillary wall is more serious. Recently, the use of polymer solution above its entanglement threshold in the presence of EOF has been demonstrated in the separation of small DNA as well as kilobase DNA markers by our group $[25,26]$. In the presence of EOF, better resolution in the separation of DNA fragments could be achieved since DNA migrated upstream against EOF [29]. The high-resolution separation of small DNA using a very small-size capillary filled with highly viscous polymer solutions in the presence of the EOF has been demonstrated [25]. More importantly, the separation of DNA in CPGGE becomes feasible in the presence of EOF. However, it may suffer from the variation of the EOF. Thus it is very important to refresh capillary surface with $0.5 M \mathrm{NaOH}$ to minimize the adsorption of polymer molecules into the capillary wall prior to analysis. As the EOF can be well controlled, we can perform SCE for enhanc- ing efficiency in the analysis of DNA. To perform SCE for DNA analysis, the buffer vials containing different concentrations of PEO and EtB were manually changed. Thus different PEO solutions were introduced into the capillary by the EOF during the DNA analysis.

\subsection{SCE using different PEO solutions}

Fig. 4 shows the separation of DNA Markers V and VI in SCE at $15 \mathrm{kV}$, using a $1 \%$ PEO solution for $4 \mathrm{~min}$, then a $2 \%$ PEO solution for the rest of the separation time. DNA fragments larger than $51 \mathrm{bp}$ were detected in less than $16 \mathrm{~min}$. The separation time and resolution obtained in SCE were different from those obtained under two different isocratic conditions (Figs. 1, 2), indicating that DNA fragments underwent the two different polymer solutions when they migrated upstream against the EOF. For larger DNA fragments, they mostly migrated in the 


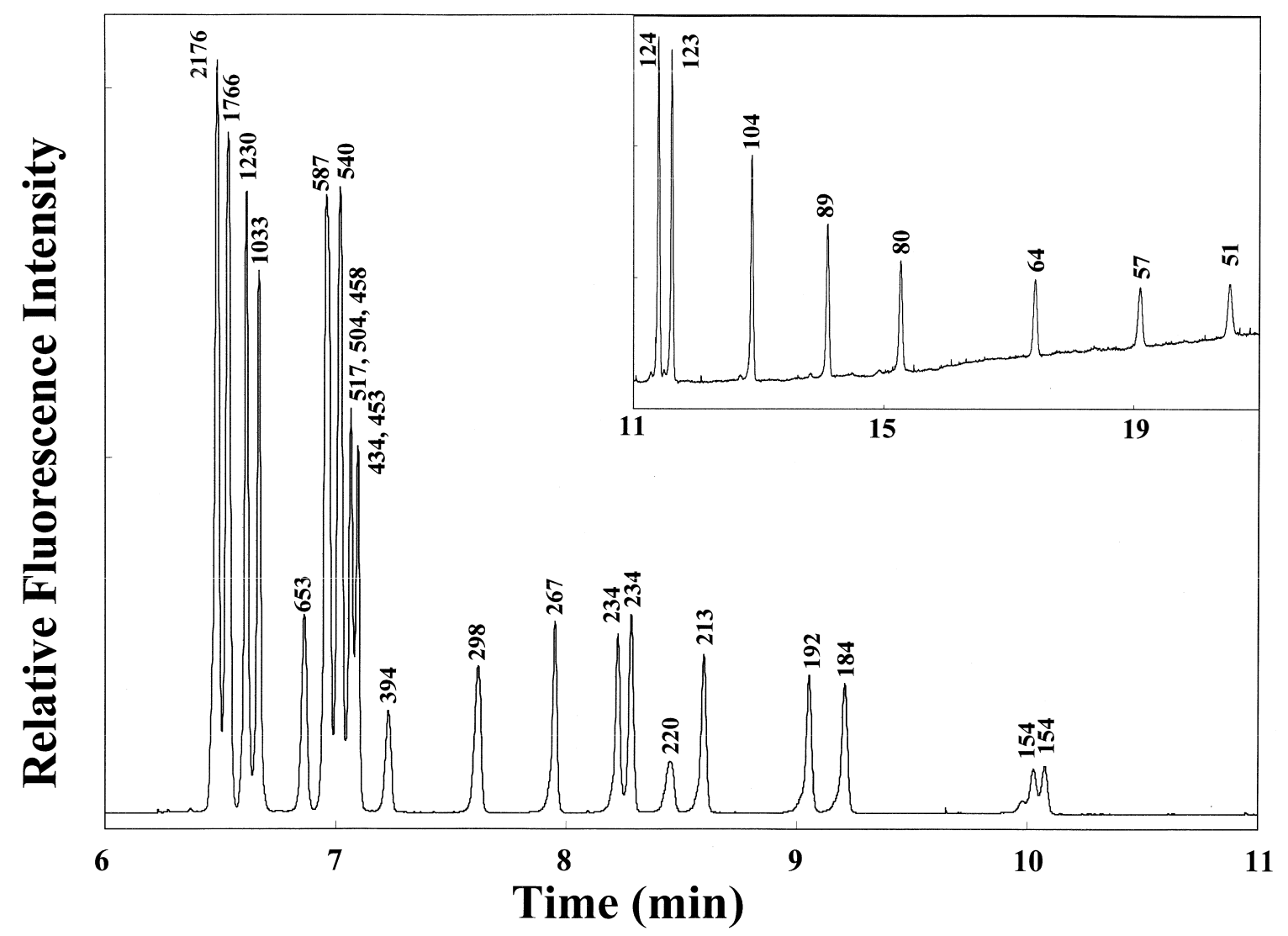

Fig. 3. Separation of DNA markers V and VI in the presence of EOF at $15 \mathrm{kV}$, using a $2 \%$ PEO solution containing $20 \mu \mathrm{g} / \mathrm{ml}$ EtB. Buffer vials contain the $2 \%$ PEO and $20 \mu \mathrm{g} / \mathrm{ml}$ EtB solution. The capillary was filled with a $1 \times \mathrm{TBE}$ solution containing $20 \mu \mathrm{g} / \mathrm{ml} \mathrm{EtB}$ Other conditions as in Fig. 1.

zone of the 1\% PEO solution, and thus resolution values between any two larger DNA fragments (larger than $653 \mathrm{bp}$ ) obtained in SCE were higher than those obtained using the isocratic means $(2 \%$ PEO). Surprisingly, two partially resolved bands of 458- and 504-bp DNA fragments were obtained, which may be due to the changes in DNA conformations when they migrated through the two different PEO solutions. The loss in resolution between two 154-bp DNA fragments is abnormal, which may be due to the changes in DNA conformations and the diffusion effects (concentration change on the interface between the two different polymer solutions). Table 1 shows the reproducibility of the migration times of some DNA fragments obtained in SCE. To prevent the variations resulting from changing the vials and all other personal reasons, we normalized the migration times based on the first peak (2176-bp DNA fragment). The R.S.D. values are less than $2 \%$, except that of the 394-bp DNA fragment. One reason for poor reproducible results of DNA fragments around $394 \mathrm{bp}$ is the diffusion problem because they migrated closely to the interface between $1 \%$ and $2 \%$ PEO solutions. The migration time of the interface estimated from the shift of the baseline (not clearly shown in the whole scale in Fig. 4) is around 7.5 min. If this is the fact, the problem of poor reproducibility should be further minimized by using two polymer solutions with similar viscosities, but different pore sizes, or by performing CPGGE using a pumping system for automatically and gradually changing polymer solutions in the injection end. Tables 2, 3 show the comparison of the migration times and resolution obtained under the two isocratic 


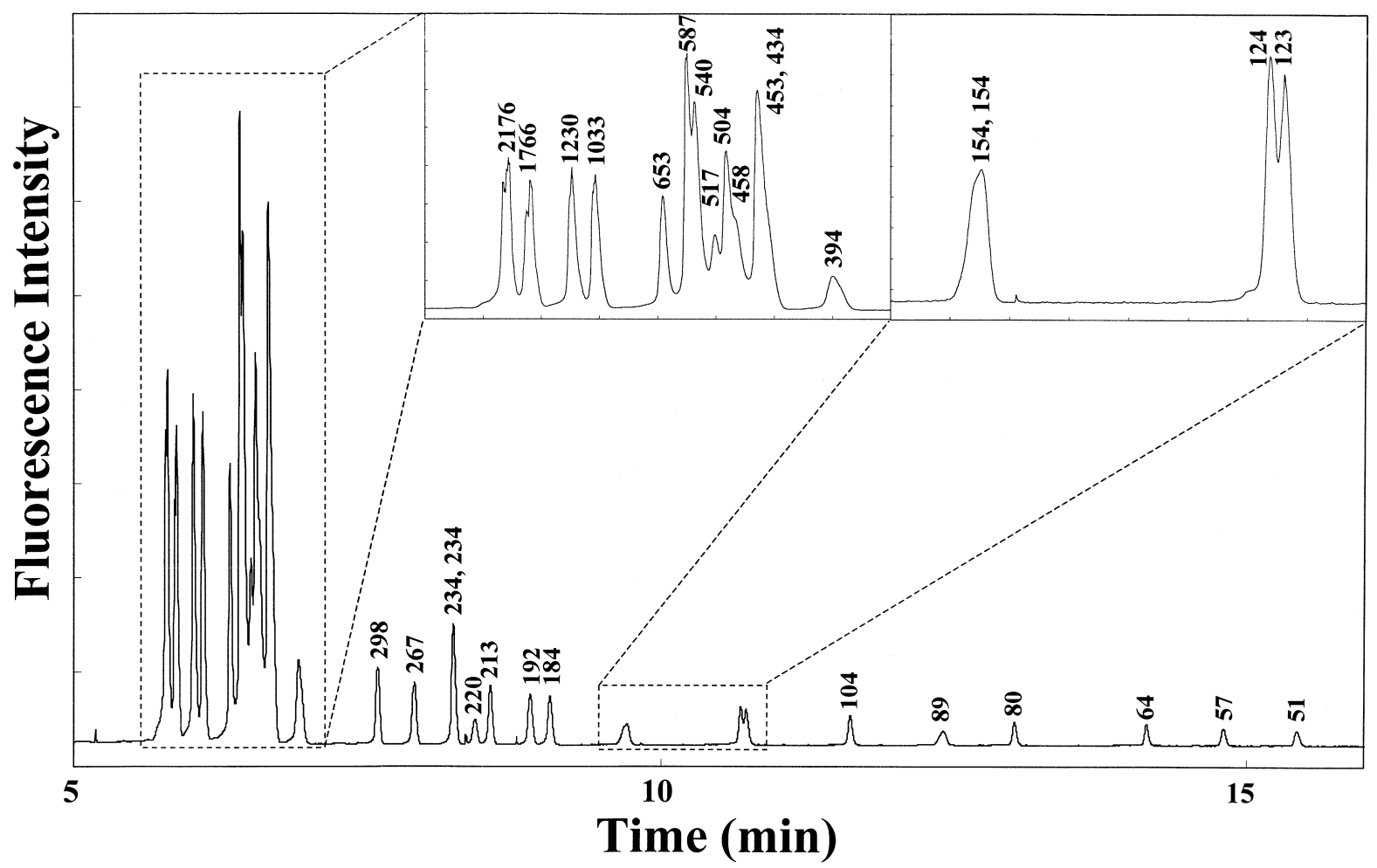

Fig. 4. Separation of DNA markers V and VI at $15 \mathrm{kV}$ in SCE, using a $1 \%$ PEO solution containing $1 \mu \mathrm{g} / \mathrm{ml}$ EtB for $4 \mathrm{~min}$, then a $2 \%$ PEO solution containing $1 \mu \mathrm{g} / \mathrm{ml} \mathrm{EtB}$ for the rest of the separation. Buffer vials contain the $2 \%$ PEO and $1 \mu \mathrm{g} / \mathrm{ml}$ EtB solution. Other conditions as in Fig. 1.

Table 1

Reproducibility of migration times of some DNA fragments in SCE

\begin{tabular}{|c|c|c|c|c|c|}
\hline \multirow{2}{*}{$\begin{array}{l}\text { Base pair } \\
2176\end{array}$} & \multicolumn{2}{|c|}{$\begin{array}{l}\text { Normalized } \\
\text { time (min) }\end{array}$} & migration & \multirow{2}{*}{$\begin{array}{r}\text { Mean } \\
5.79\end{array}$} & \multirow{2}{*}{$\frac{\operatorname{RSD}(\%)^{\mathrm{a}}}{0.00}$} \\
\hline & 5.79 & 5.79 & 5.79 & & \\
\hline 1766 & 5.86 & 5.87 & 5.86 & 5.86 & 0.10 \\
\hline 1230 & 6.01 & 6.00 & 6.00 & 6.00 & 0.09 \\
\hline 1033 & 6.09 & 6.10 & 6.07 & 6.09 & 0.22 \\
\hline 653 & 6.32 & 6.47 & 6.29 & 6.36 & 1.51 \\
\hline 394 & 6.90 & 7.53 & 7.23 & 7.22 & 4.38 \\
\hline 298 & 7.58 & 7.84 & 7.70 & 7.71 & 1.71 \\
\hline 234 & 8.22 & 8.35 & 8.38 & 8.32 & 1.03 \\
\hline 213 & 8.54 & 8.68 & 8.71 & 8.64 & 1.06 \\
\hline 123 & 10.72 & 10.88 & 10.91 & 10.83 & 0.92 \\
\hline 64 & 14.14 & 14.42 & 14.48 & 14.35 & 1.28 \\
\hline 51 & 15.43 & 15.68 & 15.74 & 15.62 & 1.05 \\
\hline
\end{tabular}

${ }^{\mathrm{a}} \mathrm{A} 1 \%$ PEO solution was introduced into the capillary for 4 $\min$ at $15 \mathrm{kV}$, then a $2 \%$ PEO solution during the separation.
Table 2

Comparison of the migration times of some DNA fragments in isocratic and stepwise separations

\begin{tabular}{lrrrrl}
\hline Base pair & \multicolumn{6}{l}{ Migration time (min) } \\
\cline { 2 - 6 } & $\mathrm{A}^{\mathrm{a}}$ & \multicolumn{1}{c}{$\mathrm{B}$} & \multicolumn{1}{l}{$\mathrm{C}$} & \multicolumn{1}{l}{$\mathrm{D}$} & $\mathrm{E}$ \\
\hline 2176 & 6.36 & 6.25 & 6.00 & 5.79 & 5.42 \\
1766 & 6.41 & 6.29 & 6.05 & 5.86 & 5.48 \\
1230 & 6.55 & 6.40 & 6.17 & 6.01 & 5.58 \\
1033 & 6.64 & 6.47 & 6.25 & 6.09 & 5.64 \\
653 & 6.82 & 6.63 & 6.43 & 6.23 & 5.81 \\
394 & 7.20 & 6.99 & 6.81 & 6.90 & 6.18 \\
298 & 7.69 & 7.45 & 7.30 & 8.12 & 6.63 \\
234 & 8.32 & 8.01 & 7.91 & 8.22 & 7.24 \\
213 & 8.66 & 8.30 & 8.24 & 8.54 & 7.55 \\
123 & 11.21 & 10.25 & 10.51 & 10.72 & 9.55 \\
64 & 16.21 & 13.53 & 14.43 & 14.14 & N.D. \\
51 & 18.67 & 14.98 & 16.18 & 15.43 & N.D. \\
\hline
\end{tabular}

${ }^{\mathrm{a}} \mathrm{A}$ and $\mathrm{E}: 2 \%$ and $1 \%$ PEO solutions under isocratic conditions. B, C, and D: a $1 \%$ PEO solution was introduced into the capillary for $0.5,1$, and $4 \mathrm{~min}$, respectively, at $15 \mathrm{kV}$, then a $2 \%$ PEO solution during the separation. 
Table 3

Comparison of some of the resolution values in the separation of DNA fragments under isocratic and stepwise conditions

\begin{tabular}{llllll}
\hline Base pair & \multicolumn{2}{l}{ Resolution } \\
\cline { 2 - 6 } & $\mathrm{A}^{\mathrm{a}}$ & $\mathrm{B}$ & $\mathrm{C}$ & $\mathrm{D}$ & $\mathrm{E}$ \\
\hline $540 / 587$ & 1.57 & 1.42 & 1.44 & 0.59 & 0.49 \\
$504 / 453$ & 0 & 0 & 0 & 0.46 & 0 \\
$154 / 154$ & 0.8 & 0.67 & 0.66 & 0.57 & 0.53 \\
$123 / 124$ & 0.56 & 0.10 & 0.22 & 0.72 & 1.82 \\
\hline
\end{tabular}

${ }^{\mathrm{a}} \mathrm{A}$ and $\mathrm{E}: 2 \%$ and $1 \%$ PEO solutions under isocratic conditions. B, C, and D: a $1 \%$ PEO solution was introduced into the capillary for $0.5,1$, and $4 \mathrm{~min}$, respectively, at $15 \mathrm{kV}$, then a $2 \%$ PEO solution during the separation.

conditions and in SCE using various fractions of two different PEO solutions during the separation. As the results shown in Table 2, the migration times of DNA fragments larger than $653 \mathrm{bp}$ become shorter with the increase in the fraction of the $1 \%$ PEO solution inside the capillary during the separation. This again indicates that the EOF is smaller in the $2 \%$ PEO solution. On the other hand, the migration times of the smaller DNA fragments changed irregularly. When small DNA fragments migrated through the interface between the $1 \%$ and $2 \%$ PEO solutions, DNA conformations might change and concentration diffusion might also affect the migration of DNA. The slight change in resolution shown in Table 3 may be due to the effects of different viscosity and pore sizes of the two PEO solutions. It is interesting to note that the peaks of two 154-bp DNA fragments were not resolved when the $1 \%$ PEO solution was introduced for a short period of time. This may be due to the diffusion problem in such a narrower $1 \%$ PEO zone between $1 \times \mathrm{TBE}$ and $2 \%$ PEO solutions. From the changes in migration time and resolution in SCE under different conditions, we know that DNA should undergo two different PEO solutions during the separation.

\subsection{SCE using different EtB and PEO}

In an attempt to shorten the separation time and enhance the sensitivity of detecting smaller DNA fragments, we performed the DNA separation using different concentrations of EtB. Fig. 5 shows the separation of DNA markers $\mathrm{V}$ and VI in less than 15 min at $15 \mathrm{kV}$ in SCE, using a $2 \%$ PEO solution containing $1 \mu \mathrm{g} / \mathrm{ml} \mathrm{EtB}$ for $4 \mathrm{~min}$, then a $2 \%$ PEO solution containing $20 \mu \mathrm{g} / \mathrm{ml} \mathrm{EtB}$ for the rest of the separation. In this case, it has a less chance for larger DNA fragments than smaller DNA fragments undergoing the PEO zone with higher EtB. Thus resolution values between any two larger DNA fragments (larger than $653 \mathrm{bp}$ ) obtained from SCE are higher than those obtained under isocratic conditions (20 $\mu \mathrm{g} / \mathrm{ml} \mathrm{EtB})$. In other words, EtB molecules might have more significant effects on the change in the conformation of smaller DNA fragments during the separation. It is therefore that the total separation time obtained in SCE is in the range of those obtained under two isocratic conditions (1 and 20 $\mu \mathrm{g} / \mathrm{ml} \mathrm{EtB)}$.

To test the effects of the changes in the net charges and conformations of DNA as well as the properties (such as pore size) of polymer solutions on the DNA analysis, we performed the separation in SCE, using solutions containing different concentrations of PEO and EtB. Fig. 6 shows the separation of DNA markers $\mathrm{V}$ and VI in $15 \mathrm{~min}$ at $15 \mathrm{kV}$ via SCE, using a $1 \%$ PEO solution containing $1 \mu \mathrm{g} / \mathrm{ml}$ EtB for $4 \mathrm{~min}$, then a $2 \%$ PEO solution containing $20 \mu \mathrm{g} / \mathrm{ml} \mathrm{EtB}$ for the rest of the separation time. Results again show that 458- and 504-bp DNA fragments were partially resolved. Furthermore, the resolution values between any two DNA fragments larger than $653 \mathrm{bp}$ and between 123- and 124-bp fragments are higher than those obtained in Fig. 5. EtB $>$ DNA. When the concentrations of EtB and PEO were simultaneously changed in SCE, $20 \mu \mathrm{g} /$ $\mathrm{ml}$ EtB (cations) migrated into the 1\% PEO (neutral) solution to undergo DNA in the separation. Thus the result should also be partially reflected in that obtained in the 1\% PEO solution containing 20 $\mu \mathrm{g} / \mathrm{ml}$ EtB. Table 4 shows the comparison of the results obtained from two isocratic conditions (Figs. 2, 3) and two stepwise conditions (Figs. 5, 6). Obviously, resolution in the separation of DNA fragments was varied using different concentrations of PEO and EtB in SCE. It is interesting to note that partially resolved bands of 458- and 504-bp DNA fragments were only achieved in the stepwise change in PEO, not in EtB. Overall, the results also suggest that modification of the DNA conformations by adding suitable concentrations and species of intercalating dyes and creating pore gradient inside the 


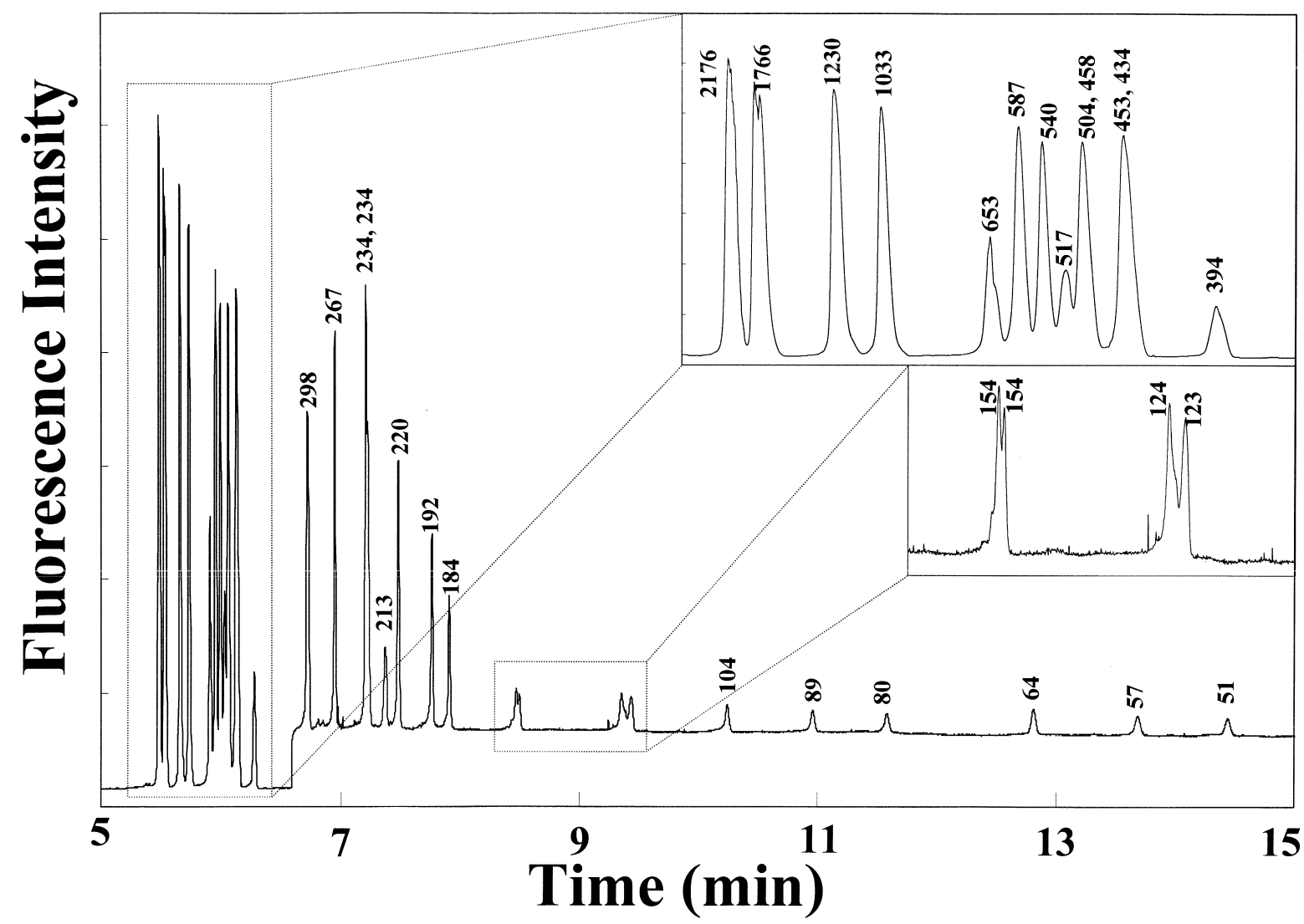

Fig. 5. Separation of DNA markers V and VI at $15 \mathrm{kV}$ in SCE, using a $2 \%$ PEO solution containing $1 \mu \mathrm{g} / \mathrm{ml}$ EtB for $4 \mathrm{~min}$, then a $2 \%$ PEO containing $20 \mu \mathrm{g} / \mathrm{ml} \mathrm{EtB}$ for the rest of the separation. Buffer vials contain the $2 \%$ PEO and $20 \mu \mathrm{g} / \mathrm{ml} \mathrm{EtB}$ solution. Other conditions as in Fig. 2.

capillary with suitable polymer solutions can be useful for enhancing the separation efficiency in DNA analysis.

\section{Conclusion}

In this work, we have demonstrated a new approach for the DNA analysis with single-base resolution in the presence of EOF. The high-speed and high-resolution separation results in the analysis of DNA, suggesting the potential of SCE in many applications, such as DNA sequencing and the analysis of PCR products. Another features of SCE is its capability of changing the separation range, time and resolution in the analysis of macromole- cules by introducing suitable dyes, polymer solution, and electrolytes in the presence of EOF during the separation.

Although a dramatic enhancement in separation efficiency of the DNA analysis has not been achieved in this preliminary experiment, the results do suggest the potential of this new approach in the analysis of macromolecules. To minimize diffusion problems occurred in the interface between two polymer solutions, gradient techniques using a pump to introduce different polymer solutions with slight changes in viscosity might be needed. Thus one of our future goals is to develop gradient techniques, using suitable polymer solutions and dyes for enhancing the separation efficiency in the separation of DNA or proteins with a wide size range. 


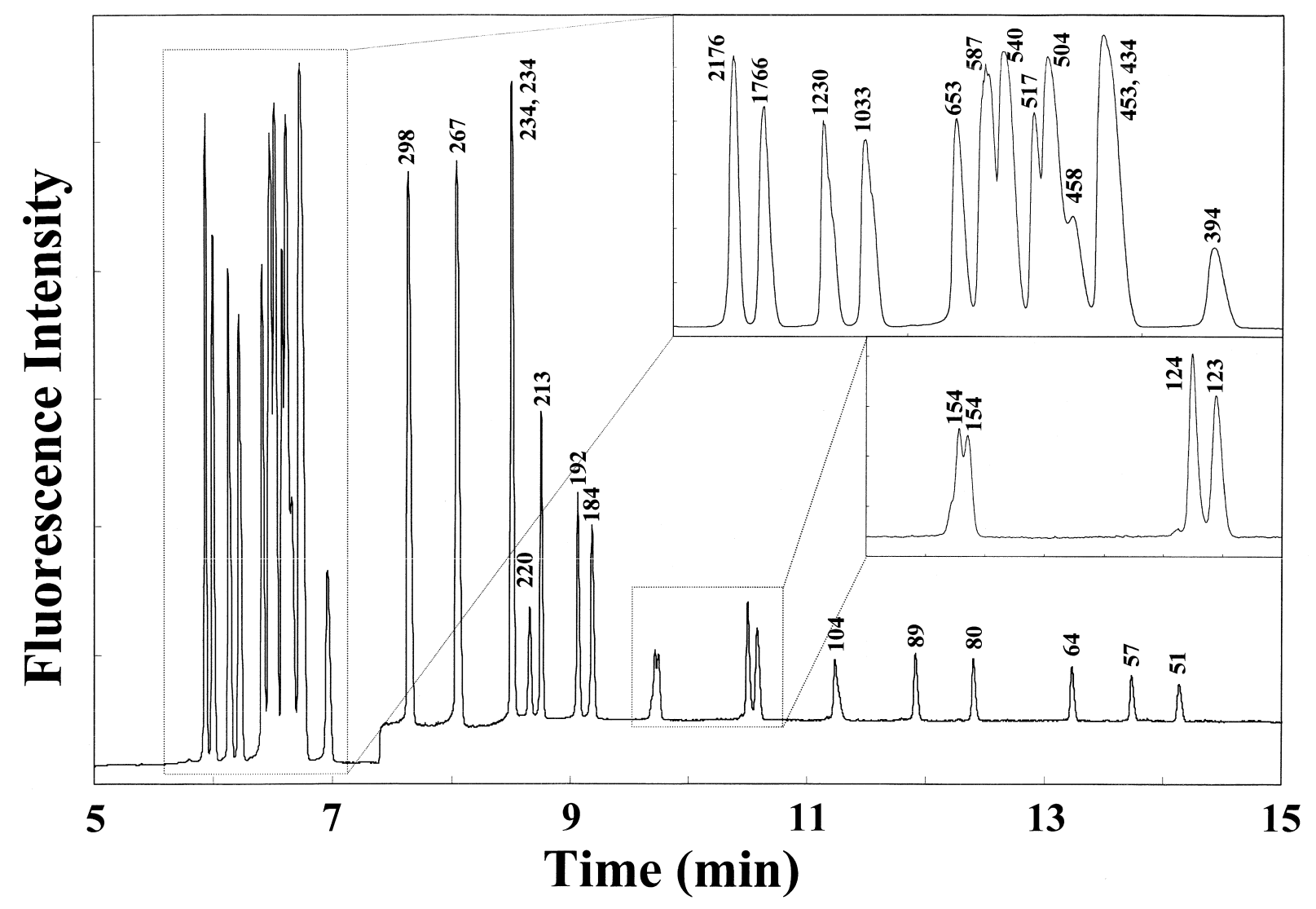

Fig. 6. Separation of DNA markers V and VI at $15 \mathrm{kV}$ in SCE, using a $1 \%$ PEO solution containing $1 \mu \mathrm{g} / \mathrm{ml}$ EtB for $4 \mathrm{~min}$, then a $2 \%$ PEO solution containing $20 \mu \mathrm{g} / \mathrm{ml} \mathrm{EtB}$ for the rest of the separation. Buffer vials contain the $2 \%$ PEO and $20 \mu \mathrm{g} / \mathrm{ml} \mathrm{EtB}$ solution. Other conditions as in Fig. 2.

Table 4

Comparison of some of the resolution values in the separation of DNA fragments under isocratic conditions, stepwise changes in EtB, and EtB and PEO

\begin{tabular}{lllll}
\hline Base pair & \multicolumn{4}{l}{ Resolution } \\
\cline { 2 - 5 } & $\mathrm{A}^{\mathrm{a}}$ & $\mathrm{B}$ & $\mathrm{C}$ & $\mathrm{D}$ \\
\hline $517 / 504$ & 1.50 & 0.00 & 0.94 & 0.89 \\
$504 / 458$ & 0.00 & 0.00 & 0.00 & 0.74 \\
$234 / 234$ & 0.00 & 1.67 & 0.52 & 0.30 \\
$154 / 154$ & 0.89 & 1.01 & 0.72 & 0.59 \\
$124 / 123$ & 0.00 & 3.54 & 1.55 & 1.73 \\
\hline
\end{tabular}

\section{Acknowledgements}

This work is supported by a grant from National Science Council of the Republic of China (No. NSC 88-2113-M002-002).

\section{References}

[1] K. Benedek, A. Guttman, J. Chromatogr. A 680 (1994) 375.

[2] V. Dolnik, M. Novotny, J. Microcol. Sep. 4 (1993) 515.

[3] K. Kleparnik, Z. Mala, P. Bocek, J. Chromatogr. A 772 (1997) 243.

[4] Y. Fang, J.Z. Zhang, J.Y. Hou, H. Lu, N.J. Dovichi, Electrophoresis 17 (1996) 1436.

[5] A.E. Barron, W.M. Sunada, H.W. Blanch, Electrophoresis 17 (1996) 744. 
[6] N. Iki, E.S. Yeung, Anal. Chem. 68 (1996) 4321.

[7] E. Carrilho, M.C. Ruiz-Martinez, J. Berka, I. Smirnov, W. Goetzinger, A.W. Miller, D. Brady, B.L. Karger, Anal. Chem. 68 (1996) 3305.

[8] S.M. Clark, R.A. Mathies, Anal. Chem. 69 (1997) 1355.

[9] H.R. Reese, Biopolymers 34 (1994) 1349.

[10] C. Carlsson, A. Larsson, M. Jonsson, Electrophoresis 17 (1996) 642.

[11] C. Carlsson, M. Jonsson, Macromolecules 29 (1996) 7802.

[12] Y. Kim, M.D. Morris, Anal. Chem. 66 (1994) 1168.

[13] H. Swerdlow, B.J. Jones, C.T. Witter, Anal. Chem. 69 (1997) 848.

[14] Y. Baba, J. Chromatogr. B 687 (1996) 271.

[15] H.R. Reese, Biopolymers 34 (1994) 1349.

[16] G. Gelfi, P.G. Righetti, L. Cremonesi, M. Ferrari, Electrophoresis 15 (1994) 1506

[17] G. Gelfi, P.G. Righetti, L. Cremonesi, M. Ferrari, Biotechniques 21 (1996) 926.

[18] E. Gombocz, A. Chrambach, Electrophoresis 12 (1991) 997.
[19] J.S. Fawcett, D. Wheeler, A. Chrambach, J. Biochem. Biophys. Methods 24 (1992) 181.

[20] H. T. Chang, E.S. Yeung, J. Chromatogr. B 669 (1995) 113.

[21] Y. Chen, F. L. Wang, U. Schwarz, J. Chromatogr. A 772 (1997) 129.

[22] T. Kaneta, H. Jeong, E.S. Yeung, J. High. Resolut. Chromatogr. 21 (1998) 287.

[23] X.C. Huang, M.A. Quesada, R.A. Mathies, Anal. Chem. 64 (1992) 2149

[24] H. Swerdlow, J.Z. Zhang, D.Y. Chen, H.R. Harke, R. Grey, S. Wu, N.J. Dovichi, C. Fuller, Anal. Chem. 63 (1991) 2835.

[25] H.S. Chen, H.T. Chang, Anal. Chem. 71 (1999), in press.

[26] H.S. Chen, H.T. Chang, Electrophoresis 19 (1998) 3149.

[27] H. Oana, R.W. Hammond, J.J. Schwinefus, S. C. Wang, M. Doi, M.D. Morris, Anal. Chem. 70 (1998) 574.

[28] S. Nathakarnkitkool, P.J. Oefner, G. Bartsch, M.A. Chin, G.K. Bonn, Electrophoresis 13 (1992) 18.

[29] A.E. Barron, H.W. Blanch, D.S. Soane, Electrophoresis 15 (1994) 64 